\title{
Development of Digital Comics Based on Problem Based Learning in Accounting Learning at Vocational Schools in Surakarta
}

\author{
Laila Rossana*, Siswandari, Sudiyanto
}

Faculty of Teacher Training and Education, Sebelas Maret University, Indonesia

Email: lailarossana7@gmail.com

\begin{abstract}
The learning of the 21st century is directed, among others, at the optimal use of technology and information. Optimal use of information technology is intended to increase students' motivation and critical thinking skills. But in reality, the use of instructional media in accounting learning in Vocational Schools in Surakarta has not been optimal so that learning feels boring. The purpose of this study is to develop PBL-based digital comics as a suitable learning media for accounting. The development model used in this research is the Borg \& Gall development model which Thiagarajan modified into three stages, namely define, design, and develop. Data collection techniques using a questionnaire. From the results of the feasibility test on the use of media obtained the following evaluation, media experts 93.6\%, linguists 100\%, material experts 93\%, and practitioners $84.5 \%$. Besides that, the results of limited trials showed positive responses from students by $85.20 \%$. The results of this study conclude that PBL-based digital comics are appropriate for use in accounting learning. Keywords-PBL-based digital comics, Accounting Learning
\end{abstract}

\section{INTRODUCTION}

The amount of information available and the ease of accessing information in the $21 \mathrm{st}$ century marks the development of information technology which is very rapid. Very rapid technological developments, creating opportunities for educators or teachers to utilize these technologies to support teaching and learning processes and activities in the classroom and outside the classroom [1]-[3]. This has also changed the 21st-century learning paradigm to utilize technology and information optimally. Optimal use of information technology is intended to increase students motivation and critical thinking skills.

That is because motivation and critical thinking skills become important provisions for students to be able to compete and survive. High motivation in students indicates that students have toughness. Where toughness is one of the keys to success because students can withstand failure and make the right decisions. [4]. Similarly, the importance of critical thinking skills for students. One of the 21 st-century skills that need to be trained by teachers to students as the provision of future life is critical thinking skills [5]. In line with the importance of motivation and critical thinking skills in students, learning needs to be organized by utilizing the use of instructional media and information technology that can facilitate the growth of motivation and critical thinking skills in students.
Based on observations and interviews with accounting teachers who teach vocational schools in the Surakarta region, it is found that the use of accounting learning media and information technology is still not optimal. Learning is considered boring coupled with a material that is difficult for students to understand, making a low motivation to learn in students. The low motivation of students is shown through a questionnaire that has been distributed to students, with an average of 50,29. Researchers also found that the average critical thinking skills of students were also still relatively low, amounting to 53,99

Based on the above problems and the demands of $21 \mathrm{st}-$ century learning, it is necessary to hold fun learning, can attract attention, and makes it easier for students to understand the material by utilizing technological sophistication. This can be done using learning media that utilizes technology combined with an appropriate learning model.

The media has a positive contribution to learning, namely facilitating the delivery of messages, learning more interesting and interactive, and can develop positive attitudes of students towards the learning process implemented [6]. Nowadays technological advances have changed the way of understanding literacy, and are no longer limited to interactions with printed texts [7]. In 
addition to using learning media, learning models also have an important role in helping students succeed and make the most significant contribution to student learning outcomes [8]. Theoretically, the above problems can be overcome by developing digital comic media based on PBL (Problem Based Learning)

Digital comics are one of the most popular types of learning media because they are much sought after by readers. This is supported by the popularity of webtoon (digital comics originating from Korea) among adolescents as seen from the increased consumption of web content in the global cartoon market [9]. Digital comics are presented with humorous, narrative, and visual features that make reading fun and easy to understand [10]. Comics have a simple nature, presenting stories that contain messages that are easy to digest [11].

Based on the results of preliminary studies conducted by researchers, data obtained that as much as $86.36 \%$ of students liked to read comics and picture stories. The advantages of comics, which are liked by many students, are one of the opportunities that can be utilized by teachers in developing learning media that are more interesting and enjoyable. This is supported by the results of research which state that Andro-web comics are suitable for use in learning, can be used as an alternative for teachers to attract students' attention and help students learn easily and practically because they provide illustrations that ascend in simple language based on the results of preliminary studies conducted by researchers, data obtained that as much as $86.36 \%$ of students liked to read comics and picture stories. The advantages of comics, which are liked by many students, are one of the opportunities that can be utilized by teachers in developing learning media that are more interesting and enjoyable. This is supported by the results of research which state that Andro-web comics are suitable for use in learning, can be used as an alternative for teachers to attract students' attention and help students learn easily and practically because they provide illustrations that ascend in simple language [12], [13].

PBL is a learning model that makes problems an important starting point in learning [14]. The problem presented in learning by the PBL method is a problem that has a context with the real world, the more realistic the problem presented is increasingly improving student skills. The purpose of learning with the PBL model is to improve students' analytical skills [15], [16]. This is by the characteristics of accounting material, where students need analytical skills, and reasoning in understanding material and doing accounting problems.

PBL-based digital comics are comics whose contents contain messages or information about learning accounting, where the storyline is integrated with the PBL learning model syntax carried out with the stages of the PBL learning model. Problems in the PBL learning model can be presented in the form of story scripts, pictures, videos or films [14]. The selection of comic media is based on the characteristics of the comic itself that pack the message into a story accompanied by pictures and words that attract students' attention. Adjusting journal material requires analytical skills that can be directed through PBL learning models that present contextual problems so that students will conduct analyzes in solving the problems presented.

Some relevant studies have tested the effectiveness of PBL-based comic media, and have been proven to be feasible and effective for use in learning [17], [18]. The results of Fatimah and Widiyatmoko's research show that PBL-based science comics are considered very feasible by media, material and language experts[17]. Its effectiveness is demonstrated through an increase in learning outcomes and thinking skills in students. Ayuni suggested the development of PBL-based comic learning media with other material so that it attracts students to enjoy learning[18]. However, the use of PBL-based comic media in accounting learning is still rarely used.

Referring to the need for using media that utilize the technology, teachers as educators are expected to be able to develop learning media that utilize technology to create interesting, fun learning and make it easier for students to learn. Based on the results of observations and interviews as well as previous research studies, it is necessary to develop PBL-based digital comics as a learning media that is interesting, fun and makes it easier for students to understand the adjusting journal material.

\section{RESEARCH METODOLOGY}

\section{Research Locations and Subjects}

This research was conducted at State Vocational Schools in the Surakarta region. The subjects in the limited trial were class XI students of SMK Negeri 1 Surakarta. Based on random sample selection, I obtained class XI Ak 2. The number of research trial subjects was ten students.

\section{Research Methods and Procedures}

This type of research is a Research and Development (R \& D) research by referring to the Borg \& Gall development model which Thiagarajan modified into three stages, namely define, design, and develop. The define stage is conducting observations to see the material requirements needed by students and observing the character of students in the class. The design stage is designing prototypes or frameworks of teaching materials that will be created and adjusted to the needs analysis and character analysis of 
students. The develop phase includes the validation stage of teaching materials that have been made to the validators consisting of media expert validators, language expert validators, material expert validators, and practitioner validators and limited trials.

Validation and testing aim to control the content of teaching materials to keep them by the needs and characteristics of students. The revision process was then carried out to perfect PBL-based digital comics from various aspects. Revisions are based on suggestions and input from expert validators mentioned in the data presentation section, as well as verbal suggestions during discussions with material experts [19].

The types of data used in this study are qualitative and quantitative. Qualitative data were obtained from criticisms and suggestions from validators and trial correspondents. Quantitative data were obtained from validation data from validators and small-scale trial data for 10 students. The instruments in this research and development are in the form of expert validation sheets and product trial correspondents. Lattice of development research instruments are in table 1 , table 2 , table 3 , table 4 and table 5 .

Table 1. Grid Expert Media Validation Sheet Grid Expert Media Validation Sheet

\begin{tabular}{|c|c|}
\hline Aspects & Indicator \\
\hline \multirow[t]{8}{*}{$\begin{array}{l}\text { Content/ } \\
\text { Material }\end{array}$} & $\begin{array}{l}\text { 1. Conformity of comic content } \\
\text { with Basic Competence and } \\
\text { Learning objectives }\end{array}$ \\
\hline & $\begin{array}{l}\text { 2. Clarity and suitability of the } \\
\text { language used }\end{array}$ \\
\hline & $\begin{array}{l}\text { 3. Balance the proportion of } \\
\text { practice questions / tests with } \\
\text { material }\end{array}$ \\
\hline & $\begin{array}{l}\text { 4. Accuracy of dialogue/text story } \\
\text { with the material }\end{array}$ \\
\hline & $\begin{array}{l}\text { 5. Present accurate and up-to-date } \\
\text { information }\end{array}$ \\
\hline & 6. Technical quality of the media \\
\hline & $\begin{array}{l}\text { 7. Clarity of user guides and } \\
\text { directions }\end{array}$ \\
\hline & $\begin{array}{l}\text { 8. Content and media content } \\
\text { support the level of interest and } \\
\text { student involvement }\end{array}$ \\
\hline $\begin{array}{l}\text { Presentation } \\
\text { / }\end{array}$ & $\begin{array}{l}\text { 9. The complication of presenting } \\
\text { digital comics }\end{array}$ \\
\hline Display & $\begin{array}{l}\text { 10. Presentation of interesting and } \\
\text { proportional figures }\end{array}$ \\
\hline & $\begin{array}{l}\text { 11. Layout of images and text (lay } \\
\text { out) is presented proportionally }\end{array}$ \\
\hline
\end{tabular}

\begin{tabular}{l} 
12. $\begin{array}{l}\text { Suitability of background } \\
\text { selection } \\
\text { 13. }\end{array}$ \\
$\begin{array}{l}\text { Appropriate type and font size } \\
\text { selection }\end{array}$ \\
14. $\begin{array}{l}\text { Suitability of selection and } \\
\text { color proportion } \\
\text { 15. Appropriate musi/ } \\
\text { selection }\end{array}$ \\
16. $\begin{array}{l}\text { The suitability of the animation } \\
\text { with the material }\end{array}$ \\
17. Ease and attractiveness of using \\
buttons / navigators \\
18. Attractive media design \\
\hline Programing \\
19. $\begin{array}{l}\text { Ease of use of digital comic } \\
\text { media programs }\end{array}$ \\
\hline
\end{tabular}

Table 2. The screen of Language Expert Validation Sheet

\begin{tabular}{|c|c|}
\hline Aspects & Indicator \\
\hline Straightforward & $\begin{array}{l}\text { 1. The effectiveness of } \\
\text { sentences } \\
\text { 2. Rigidity of terms } \\
\text { 3. The accuracy of sentence } \\
\text { structure }\end{array}$ \\
\hline Communicative & $\begin{array}{l}\text { 4. Readability of the message } \\
\text { 5. Appropriate use of language } \\
\text { rules } \\
\text { 6. Directions for using comics } \\
\text { clearly } \\
\text { 7. Clarity of narration and } \\
\text { stories in digital comic } \\
\text { media } \\
\text { 8. Politeness of language use }\end{array}$ \\
\hline $\begin{array}{l}\text { Conformity with } \\
\text { the level of } \\
\text { development of } \\
\text { students }\end{array}$ & $\begin{array}{l}\text { 9. Suitability of language with } \\
\text { students' level of thinking } \\
\text { 10. Ease of understanding the } \\
\text { flow of material through the } \\
\text { use of language }\end{array}$ \\
\hline Use of terms & $\begin{array}{l}\text { 11. Accuracy of terms used } \\
\text { 12. Consistent use of the term }\end{array}$ \\
\hline
\end{tabular}

Table 3. Grid of Expert Material Validation Sheet

\begin{tabular}{lrl}
\hline Aspects & Indicator \\
\hline Content/ & 1. & $\begin{array}{l}\text { Conformity of comic content with } \\
\text { Basic Competence and Learning } \\
\text { objectives }\end{array}$ \\
& 2. & Clarity of content and learning
\end{tabular}
topics

3. Coverage (breadth and depth of material)

4. The appearance of material ropes

5. Clarity of the examples included 


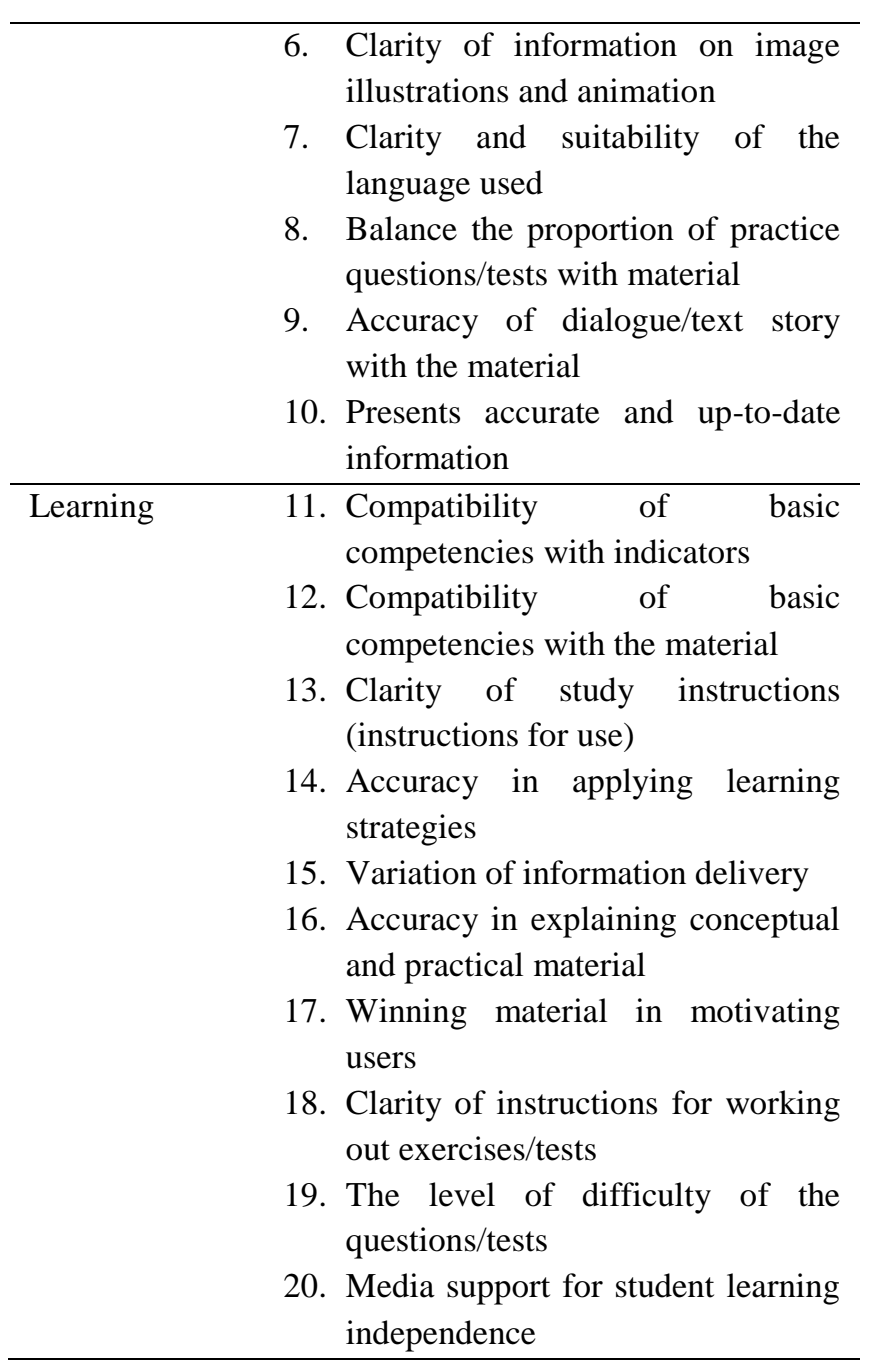

Table 4. Grid Practitioner Validation Sheet

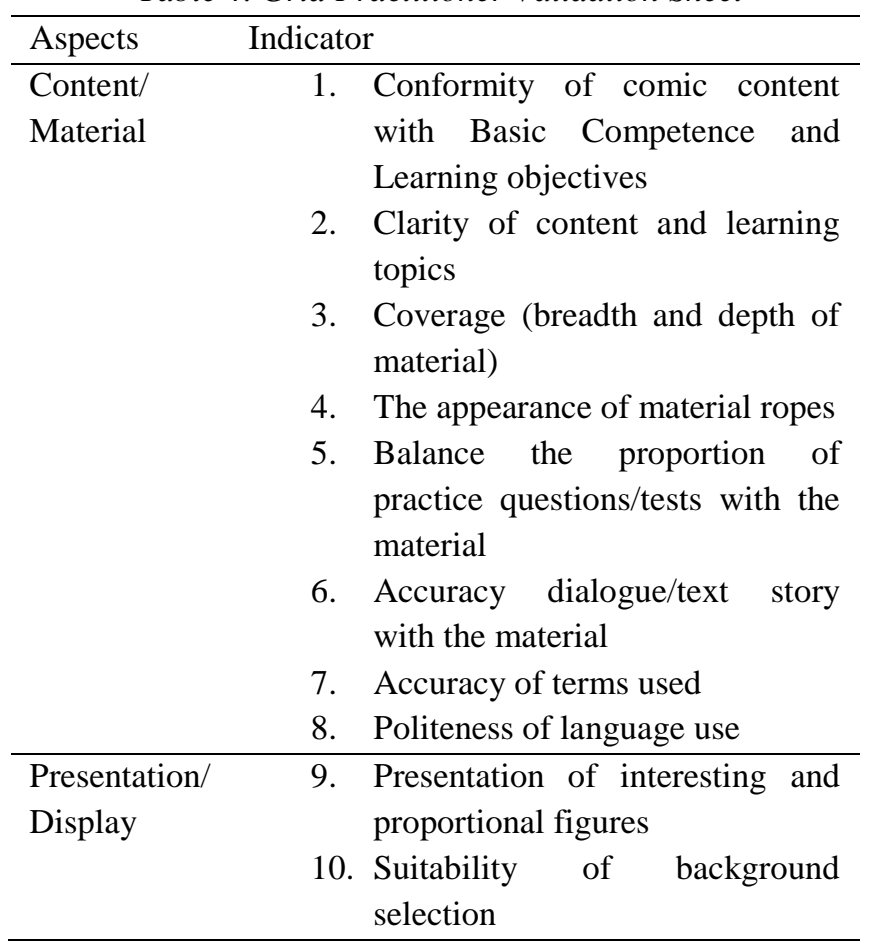

11. The appropriate type and font size selection

12. The suitability of the animation with the material

13. Ease of use of digital comic media programs

14. Speed button function (navigation performance)

15. Ease of settings to run videos

\begin{tabular}{l} 
Learning 16. $\begin{array}{l}\text { Conformity of basic } \\
\text { competencies with indicators }\end{array}$ \\
$\begin{aligned} & \text { 17. } \text { Conformity of basic } \\
& \text { competencies with the material }\end{aligned}$ \\
18. $\begin{array}{l}\text { Clarity of media titles, and target } \\
\text { users }\end{array}$ \\
19. Winning material in motivating \\
users \\
20. $\begin{array}{l}\text { Media support for student } \\
\text { learning independence }\end{array}$ \\
\hline
\end{tabular}

Table 5. Limited Try Trial Validation Sheet (Student Response)

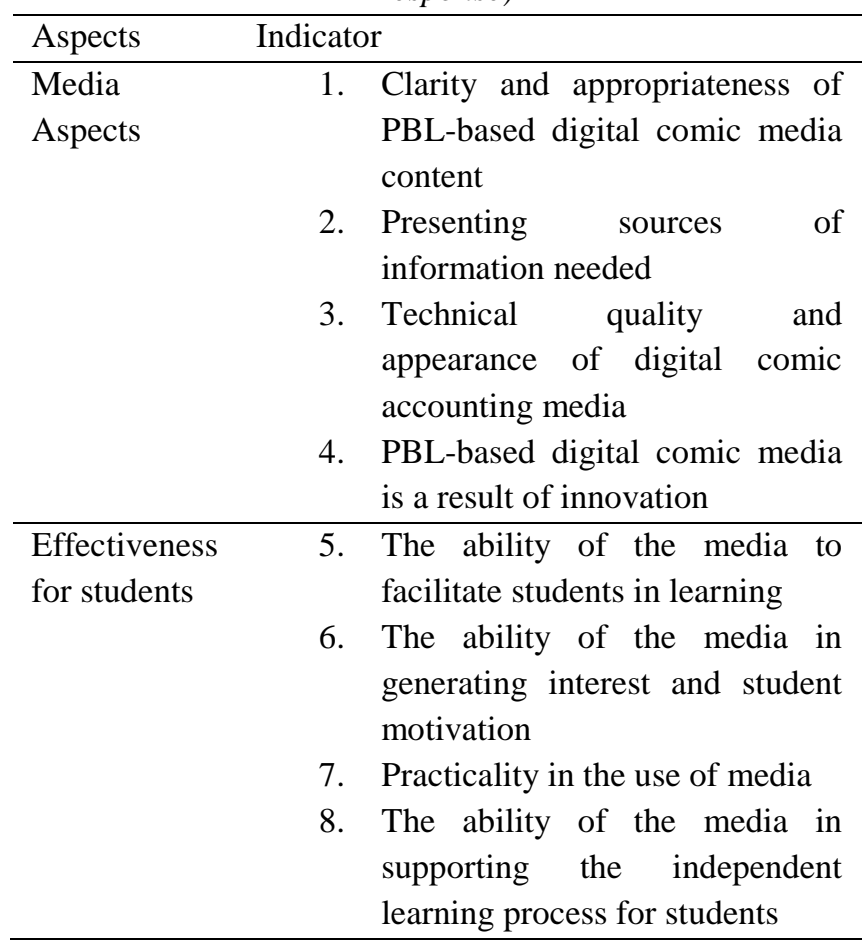

Quantitative data in the form of expert validation results and trials are limited to students in the form of questionnaire scores. The questionnaire filling data refers to the Likert scale filling method with 5 choices for each component presented. This data is in the form of numbers which are $5,4,3,2,1$. The numbers are then qualitatively so that it can be concluded that the validity level of PBLbased digital comics is developed. Questionnaire answers 
using a Likert scale which includes five choices are presented in Table 6. Quantitative data in the form of expert validation results and trials are limited to students in the form of questionnaire scores. The questionnaire filling data refers to the Likert scale filling method with 5 choices for each component presented. This data is in the form of numbers which are 5, 4, 3, 2, 1. The numbers are then qualitatively so that it can be concluded that the validity level of PBL-based digital comics is developed. Questionnaire answers using a Likert scale which includes five choices are presented in Table 6.

Table 6. Questionnaire Answer Criteria with Likert Scale

\begin{tabular}{cc}
\hline Category & Score \\
\hline SB (Very good) & 5 \\
\hline B (Good) & 4 \\
\hline C (Enough) & 3 \\
\hline K (Less) & 2 \\
\hline SK (Very less) & 1
\end{tabular}

Source : [20]

Data collection techniques used are quantitative descriptive data analysis, used to process data from the results of the validation of media experts, languages, materials, practitioners and student respondents in the form of input suggestions and criticisms of improvements contained in the validation instrument questionnaire and qualitative descriptive statistical analysis used to analyze data obtained in the form of percentage analysis. Data collected on the trial questionnaire validation sheet was first converted into quantitative data by the score weights. Changes are made using the following formula.

The total number of

$\begin{array}{ll}\text { Percentage }= & \text { answer items } \\ \begin{array}{l}\text { The ideal number of } \\ \text { scores for all items }\end{array}\end{array}$

Note: The ideal number of scores for all items is obtained from the highest answer score $\mathrm{x}$ number of instruments $\mathrm{x}$ number of respondents [20]

The validity criteria of the validator assessment questionnaire data can be viewed from the results of the percentage of criteria in Table 7.

Table 7. Validity Criteria Questionnaire Evaluation

\begin{tabular}{ll} 
& Questionnaire Data \\
\hline Score Interval & Criteria \\
\hline $0 \%-20 \%$ & Very bad \\
\hline $21 \%-40 \%$ & Not good \\
\hline $41 \%-60 \%$ & Enough \\
\hline $61 \%-80 \%$ & Well \\
\hline $81 \%-100 \%$ & Very Good \\
\hline
\end{tabular}

Source: [21]
In development research, it was determined that the product produced was said to be suitable for use if it had fulfilled the "Good" value.

\section{RESULT AND DISCUSSION}

Research into the development of PBL-based digital comic media produces digital comic drafts that have been validated and tested on a limited or small scale basis. Based on the results of the validation by learning media experts the average percentage of assessment results obtained by $93.6 \%$ with very good assessment criteria. A summary of the results of the media expert validation results in Table 8 . The average percentage of the results of the assessment by linguists is $100 \%$ with very good criteria. Summary of data from the validation results of linguists in Table 9. The average percentage of the results of the assessment by material experts, which is $93 \%$ with very good criteria. A summary of the data from the validation results of linguists in Table 10. The average percentage of assessment results by practitioners, which is $84.5 \%$ with very good criteria. Summary of data from the validation of linguists in Table 11.

Table 8. Summary of PBL Based Digital Comic Validation Results by Media Experts

\begin{tabular}{|c|c|c|c|c|c|c|}
\hline No & Aspects & $\begin{array}{l}\sum \\
\mathbf{n}_{\mathbf{i}}\end{array}$ & $\sum \mathbf{N}$ & $\%$ & Value & Criteria \\
\hline 1 & $\begin{array}{l}\text { Content / } \\
\text { Material }\end{array}$ & 43 & 45 & $100 \%$ & $95,56 \%$ & $\begin{array}{l}\text { Very } \\
\text { Good }\end{array}$ \\
\hline 2 & $\begin{array}{l}\text { Presentation/ } \\
\text { Display }\end{array}$ & 44 & 50 & $100 \%$ & $88 \%$ & $\begin{array}{l}\text { Very } \\
\text { Good }\end{array}$ \\
\hline 3 & Programming & 30 & 30 & $100 \%$ & $100 \%$ & $\begin{array}{l}\text { Very } \\
\text { Good }\end{array}$ \\
\hline & Total Score & 117 & 125 & $100 \%$ & $93,6 \%$ & $\begin{array}{l}\text { Very } \\
\text { Good }\end{array}$ \\
\hline
\end{tabular}

Source: Results of Data Processing in 2019

Table 9. Summary of PBL Based Digital Comic Validation Results by Linguists

\begin{tabular}{|c|c|c|c|c|c|c|}
\hline No & Aspects & $\sum \mathbf{n}_{\mathbf{i}}$ & $\sum \mathbf{N}$ & $\%$ & Value & Criteria \\
\hline 1 & $\begin{array}{l}\text { Straight- } \\
\text { forward }\end{array}$ & 15 & 15 & $100 \%$ & $100 \%$ & $\begin{array}{l}\text { Very } \\
\text { Good }\end{array}$ \\
\hline 2 & $\begin{array}{l}\text { Communi- } \\
\text { cative }\end{array}$ & 25 & 25 & $100 \%$ & $100 \%$ & $\begin{array}{l}\text { Very } \\
\text { Good }\end{array}$ \\
\hline 3 & $\begin{array}{l}\text { Appropriate } \\
\text { level of } \\
\text { student } \\
\text { development }\end{array}$ & 10 & 10 & $100 \%$ & $100 \%$ & $\begin{array}{l}\text { Very } \\
\text { Good }\end{array}$ \\
\hline 4 & Use of terms & 10 & 10 & $100 \%$ & $100 \%$ & $\begin{array}{l}\text { Very } \\
\text { Good }\end{array}$ \\
\hline $\begin{array}{l}\text { Total } \\
\text { Score }\end{array}$ & & 60 & 60 & $100 \%$ & $100 \%$ & $\begin{array}{l}\text { Very } \\
\text { Good }\end{array}$ \\
\hline
\end{tabular}

Source: Results of Data Processing in 2019 
Table 10. Summary of PBL Based Digital Comic Validation Results by Material Expert

\begin{tabular}{|c|c|c|c|c|c|c|}
\hline No & Aspects & $\sum \mathbf{n}_{\mathbf{i}}$ & $\sum \mathbf{N}$ & $\%$ & Value & Criteria \\
\hline \multirow[t]{2}{*}{1} & Content/ & 45 & 50 & $100 \%$ & $90 \%$ & Very \\
\hline & Material & & & & & Good \\
\hline \multirow[t]{2}{*}{2} & Learning & 48 & 50 & $100 \%$ & $96 \%$ & Very \\
\hline & & & & & & Good \\
\hline \multicolumn{2}{|c|}{ Total } & 93 & 100 & $100 \%$ & $93 \%$ & Very \\
\hline \multicolumn{2}{|c|}{ Score } & & & & & Good \\
\hline
\end{tabular}

Source: Results of Data Processing in 2019

Table 11. Summary of PBL Based Digital Comic Validation Results by Practitioners

\begin{tabular}{|c|c|c|c|c|c|c|}
\hline No & Aspect & $\sum \mathbf{n}_{\mathbf{i}}$ & $\sum \mathbf{N}$ & $\%$ & Value & Criteria \\
\hline 1 & $\begin{array}{l}\text { Content/ } \\
\text { Material }\end{array}$ & 65 & 80 & $100 \%$ & $81,25 \%$ & $\begin{array}{l}\text { Very } \\
\text { Good }\end{array}$ \\
\hline 2 & $\begin{array}{l}\text { Presentation/ } \\
\text { Display }\end{array}$ & 62 & 70 & $100 \%$ & $88,57 \%$ & $\begin{array}{l}\text { Very } \\
\text { Good }\end{array}$ \\
\hline 3 & Learning & 42 & 50 & $100 \%$ & $84 \%$ & $\begin{array}{l}\text { Very } \\
\text { Good }\end{array}$ \\
\hline $\begin{array}{l}\text { Total } \\
\text { Score } \\
\end{array}$ & & 169 & 200 & $100 \%$ & $84,5 \%$ & $\begin{array}{l}\text { Very } \\
\text { Good }\end{array}$ \\
\hline
\end{tabular}

Source: Results of Data Processing in 2019

Based on the assessment data by the expert team in the table above, it can be concluded that PBL-based digital comics obtain excellent ratings from media, language, material, and practitioners, and deserve to be tested and used in the accounting learning process. Furthermore, the researchers made improvements and improvements (revisions) to the initial product draft of digital accounting comics learning media. Media revision is based on suggestions and input provided by a team of experts. Data comments and suggestions by the validator of media experts, languages, materials and practitioners are presented in table 12 .

Table 12. Comments and Suggestions Validator

\begin{tabular}{lc}
\hline Validator & Comments and Suggestions \\
\hline Media & 1. $\begin{array}{l}\text { It is necessary to add the name of } \\
\text { the supervisor to the cover page }\end{array}$ \\
& 2. It is necessary to add an \\
introductory page filled with \\
acknowledgments and product \\
introductions. \\
3. The layout of the letters needs to \\
be improved \\
4he problem pages are made more \\
interesting
\end{tabular}

\begin{tabular}{ll} 
Material 1. & $\begin{array}{l}\text { The scope of material is by the } \\
\text { basic competencies and learning } \\
\text { objectives }\end{array}$ \\
2. & $\begin{array}{l}\text { Instructions for use need to be } \\
\text { improved to make it more } \\
\text { interesting }\end{array}$ \\
\hline Practitioner $\quad$ 1. & $\begin{array}{l}\text { Sound effects should be given to } \\
\text { the introductory video material }\end{array}$ \\
2. & $\begin{array}{l}\text { The scope of the material is by } \\
\text { basic competencies, just needs to } \\
\text { be deepened again } \\
\text { In the evaluation or exercise, it is } \\
\text { necessary to add knowledge and } \\
\text { type case questions }\end{array}$ \\
&
\end{tabular}

After the product was revised according to the expert team's suggestions and input, PBL-based digital comics were tested in the field. This is intended to determine the feasibility of the developed PBL-based digital comic media. Field trials are carried out on a small or limited scale, ie to 10 students. The average percentage of the results of the assessment of PBL-based digital comics by 10 students, amounting to $85.20 \%$ with very good criteria. A summary of the data on the results of assessments by students in group trials is presented in table 13 .

Table 13. Summary of PBL Based Digital Comic Media Validation Results by students in a Limited Trial

\begin{tabular}{lllllll}
\hline No & Aspects & $\begin{array}{l}\sum \\
\mathrm{ni}\end{array}$ & $\begin{array}{l}\sum_{\mathrm{N}} \\
\end{array}$ & $\begin{array}{l}\text { Valu } \\
\mathrm{e}\end{array}$ & Criteria \\
\hline $\mathbf{1}$ & Media & 338 & 400 & $100 \%$ & 84,5 & $\begin{array}{l}\text { Very } \\
\text { Good }\end{array}$ \\
\hline $\mathbf{2}$ & Media & 301 & 350 & $100 \%$ & 86,00 & $\begin{array}{l}\text { Very } \\
\text { Good }\end{array}$ \\
& Effectiveness & & & & & $\begin{array}{l}\text { Very } \\
\text { Total }\end{array}$ \\
Score & & $\mathbf{6 3 9}$ & $\mathbf{7 5 0}$ & $\mathbf{1 0 0}$ & $\mathbf{8 5 , 2 0}$ & $\%$ \\
\hline
\end{tabular}

Based on the above data it can be concluded that the use of PBL-based accounting digital comics in the accounting learning process gets positive responses from students, so PBL-based digital comics accounting learning media is declared feasible and can be used in the accounting learning process.

The advantage of the product being developed is the message content in PBL-based digital comics is by the competencies that must be achieved by students. Competency indicators become a reference in the development of PBL-based digital comics. Besides, this digital comic was developed based on the PBL development model, so that students are expected to more easily understand and analyze cases in the adjusting journal material through problems that relate concepts to everyday life. Weaknesses related to the product being 
developed are PBL-based digital comics that have only been developed to the stage of field trials and have not yet been tested for their effectiveness in actual classrooms. This PBL-based digital comic specifically discusses related adjusting journal material not yet covering the whole material in accounting learning.

\section{CONCLUSION}

Based on the results of the analysis and discussion above, it can be concluded that PBL-based digital comic products are suitable for use in accounting learning. This can be seen from the results of the assessment by media experts, languages, materials, and practitioners who stated that PBL-based digital comics are very good and deserve to be tested and used in the accounting learning process. Furthermore, based on student responses in limited trials, PBL-based digital comics get positive responses from students. So that PBL-based digital comic accounting learning media are declared feasible and can be used in the accounting learning process.

\section{SUGGESTION}

PBL-based digital comics that have been developed can be complementary media in accounting learning and can be used by students to study independently outside learning in the classroom. PBL-based digital comic media can be developed further to be more complete and more perfect, for the further development of PBL-based digital comic media can be distributed to a wider audience. Further research is needed to test the effectiveness of PBL-based digital comics that have been developed.

\section{REFERENCES}

[1] S. M. Bullock, "Digital Technologies and Diverse Learning in Teacher Education: Reassembling the Social Perspective," Explor. Pedagog. Divers. Learn. Online, vol. 25, pp. 5-23, 2015.

[2] S. Akyuz and F. Yavuz, "Digital Learning in EFL Classrooms," Procedia - Soc. Behav. Sci., vol. 197, pp. 766-769, 2015.

[3] A. All, E. P. Nuñez Castellar, and J. Van Looy, “Assessing the effectiveness of digital game-based learning: Best practices," Comput. Educ., vol. 92-93, pp. 90-103, 2016.

[4] H. K. Lukosch, G. Bekebrede, and R. Kortmann, "Simulation Gaming, Application for Suistainable Cities and Smart Infrastructures," in 48th International Simulation and Gam-ing Association Conference, 2018, pp. 45-52.

[5] Y. Maryuningsih, T. Hidayat, R. Riandi, and N. Y. Rustaman, "Critical thinking skills of prospective biology teacher on the chromosomal basic of inheritance learning through online discussion forums," J. Phys. Conf. Ser., vol. 1157, no. 2, pp. 1-6, 2019.

[6] J. E. Kemp and D. K. Dayton, Planning and Producing
Instructional Media. New York: Harper \& Row Publishers, 2010.

[7] X. Yang, L. J. Kuo, X. Ji, and E. McTigue, "A critical examination of the relationship among research, theory, and practice: Technology and reading instruction," Comput. Educ., vol. 125, pp. 62-73, 2018.

[8] A. F. Mahmud, T. Buaja, and S. A. Noh, "Problem Based Learning Model Applied: Enhancing the First Grade Students' English Achievement at Muhammadiyah Islamic School Kota Ternate," Int. J. Sci. Technol. Res., vol. 7, no. 12, pp. 270-272, 2018.

[9] J. E. Song, "Charateristics of Brand of Webtoons for Building Empathy," Asia Life Sci. Suppl., vol. 15, no. 4, pp. 2663-2678, 2018.

[10] S. F. Lin and H. S. Lin, "Learning nanotechnology with texts and comics: the impacts on students of different achievement levels," Int. J. Sci. Educ., vol. 38, no. 8, pp. 1373-1391, 2016.

[11] Y. Munadi, Media Pembelajaran: Sebuah Pendekatan Baru. Jakarta: Referensi, 2013.

[12] A. D. Lesmono, R. W. Bachtiar, Maryani, and A. Muzdalifah, "The Instructional Based Andro Web Comics on Work and Energy Topic for Senior High School Students," J. Pendidik. IPA Indones., vol. 7, no. 2, pp. 147$153,2018$.

[13] A. Widyawati and A. K. Prodjosantoso, "Pengembangan media komik IPA untuk meningkatkan motivasi belajar dan karakter peserta didik SMP," J. Inov. Pendidik. IPA, vol. 1, no. 1, pp. 24-35, 2015.

[14] A. Sujana and A. K. Jayadinata, Pembelajaran Sains di Sekolah Dasar. Sumedang: UPI Sumedang Press, 2018.

[15] B. O. Aninda and I. G. P. Suryadarma, "Penerapan PBL dengan Suplemen Komik Digital terhadap Kemampuan Pemecahan Masalah dan Sikap Peduli Lingkungan," J. Bioedukatika, vol. 5, no. 2, pp. 46-53, 2017.

[16] A. . S. Krissandi, B. Widharyanto, and R. P. Dewi, Pembelajaran Bahasa Indonesia untuk SD: Pendekatan dan Teknis. Bekasi: Media Maxima, 2018.

[17] F. Fatimah and A. Widiyatmoko, "Pengembangan science comic berbasis Problem Based Learning Sebagai Media Pembelajaran pada Tema Bunyi dan Pendengaran Untuk Siswa SMP," J. Pendidik. IPA Indones., vol. 3, no. 2, pp. 146-153, 2015.

[18] S. N. Ayuni, "Pengembangan Media Pembelajaran Komik Matematika (Komat) Berbasis Problem Based Learning (PBL) Berbantuan Software Coral Painter Pada Materi Peluang Kelas VIII SMP/MTs," Universitas Jambi, 2018.

[19] F. N. Zunaidah and M. Amin, "Pengembangan bahan ajar matakuliah Bioteknologi berdasarkan kebutuhan dan karakter mahasiswa Universitas Nusantara PGRI Kediri," J. Pendidik. Biol. Indones., vol. 2, no. 1, pp. 19-30, 2016.

[20] Sugiyono, Metode Penelitian Pendidikan: Pendekatan Kuantitatif, Kualitatif, dan R\&D. Bandung: Alfabeta, 2017.

[21] Riduwan, Skala Pengukran Variabel-variabel Penelitian. Bandung: Alfabeta, 2010. 